\title{
STUDI KOMPARASI PERILAKU WISATAWAN NUSANTARA GENERASI-X DAN MILENIAL ERA REVOLUSI INDUSTRI 4.0 DI INDONESIA
}

\author{
Dina Mayasari Soeswoyo ${ }^{1}$ \\ Sekolah Tinggi Pariwisata Bogor \\ dinamayasari3@gmail.com \\ Sekti Rahardjo ${ }^{2}$ \\ Sekolah Tinggi Pariwisata Bogor \\ sektirahardjo@gmail.com
}

\begin{abstract}
The rapid development of the tourism industry in Indonesia has also contributed to the intense level of competition among tourism destination and their supporting industries. Marketers are required to be smarter in determining the promotion tool and marketing strategies of their businesses. This survey research aims to improve understanding of the characteristics and travelling behavior from two different market segments namely Generation X (born 19651980) and Generation Y or Millennial Generation (born 1981-2000). Data collection techniques were carried out by triangulation, namely literature review, questionnaires and interviews face to face directly and through WhatssApp. The sample of respondents used was 162 Gen-X and 244 Gen-Y selected purposively, by distributing questionnaires during February 2020 to visitors who have traveled to the city of Bogor. Data analysis was performed descriptively qualitative. The result from this survey research in this case study is that Gen-X and Gen-Y have many similarities in terms of characteristics and travel behavior. Significant differences in the two generations are in the 3 attributes of respondent characteristics (gadget usage time per day, social media preferences used, travel budget) and travel behavior in the aspects of Initiation, Decision Making, When Traveling and Post-Traveling.
\end{abstract}

Keywords: Tourism Behavior, Generation -X, Millennial Generation, Bogor City Tourists

\begin{abstract}
ABSTRAK
Semakin tinggi perkembangan industri pariwisata di Indonesia turut menyebabkan ketatnya tingkat persaingan di antara para pengusaha destinasi wisata dan berbagai industri penunjangnya. Para pemasar dituntut lebih jeli dalam menentukan sarana promosi maupun strategi pemasaran usahanya. Penelitian survey ini bertujuan untuk meningkatkan pemahaman karakteristik dan perilaku berwisata dari dua segmen pasar yang berbeda yaitu Generasi-X ( kelahiran 1965-1980) dan Generasi-Y atau Generasi Millenial (kelahiran 1981-2000). Teknik pengumpulan data dilakukan secara triangulasi yaitu kajian pustaka, penyebaran kuesioner dan wawancara. Sampel responden yang digunakan adalah 162 Gen-X dan 244 Gen-Y yang dipilih secara purposive, dengan menyebarkan angket selama bulan Februari 2020 kepada para pengunjung yang pernah berwisata ke Kota Bogor. Analisis data dilakukan secara deskriptif kualitatif. Simpulan dari hasil survey pada studi kasus ini adalah bahwa Gen-X dan Gen-Y
\end{abstract}


memiliki banyak persamaan dalam hal karakteristik dan perilaku berwisata. Perbedaan yang cukup signikan pada kedua generasi tersebut adalah pada 3 atribut karakteristik responden (waktu penggunaan gadget per hari, preferensi media sosial yang digunakan, anggaran berwisata) dan perilaku berwisata pada aspek Inisiasi, Pengambilan Keputusan, Ketika Berwisata dan Paska Berwisata.

Kata Kunci : Perilaku Berwisata, Generasi-X, Generasi Milenial, Wisatawan Kota Bogor

\section{PENDAHULUAN}

Era Revolusi Industri 4.0 merupakan era baru bagi industri di mana bukan hanya menekankan penggunaan otomatisasi teknologi namun juga sudah berkembang memanfaatkan digitalisasi. Hal ini memberi dampak yang sangat besar terhadap hampir seluruh aspek kehidupan di dunia termasuk di Indonesia. Dilihat dari tingkat pertumbuhan tahunan pengguna internet dunia, tahun 2019 Indonesia menempati peringkat ke-3 terbesar dunia setelah India dan China. Rata-rata waktu yang dihabiskan penduduk dunia untuk penggunaan internet adalah 6 jam 43 menit, di antaranya digunakan untuk media sosial 2 jam 24 menit setiap harinya (Teknoia, 2020).

Di Indonesia, penetrasi pengguna internet di tahun 2018 sudah mencapai 64,8\% dari total populasi penduduk 264,16 jt jiwa. Perangkat yang digunakan pengguna internet di Indonesia yang terbanyak adalah melalui Smartphone, Laptop, Komputer Desktop dan Tablet. Adapun konten media sosial yang paling sering dikunjungi adalah Facebook (50,7\%), Instagram (17,8\%), Youtube (15,1\%), Twitter (1,7\%) kemudian Linkedin (Asosiasi Penyelenggara Jasa Internet Indonesia/APJII, 2019). Tabel 1 berikut menggambarkan pengguna internet di Indonesia berdasarkan usia :

Tabel 1.

Penetrasi Pengguna Internet di Indonesia Berdasarkan Usia

\begin{tabular}{|c|c|c|c|}
\hline Peringkat & Usia & $\%$ & $\begin{array}{l}\text { Rata-rata Pengguna } \quad \text { Internet } \\
\text { Generasi X dan Millenial (Gen-Y) }\end{array}$ \\
\hline 1 & $15-19$ & 91 & \\
\hline 2 & $20-24$ & 88,5 & \multirow{4}{*}{$79,05 \%$} \\
\hline 3 & $25-29$ & 82,7 & \\
\hline 4 & $30-34$ & 76,5 & \\
\hline 5 & $35-39$ & 68,5 & \\
\hline 6 & $40-44$ & 51,4 & \multirow{3}{*}{$46,6 \%$} \\
\hline 7 & $45-49$ & 47,6 & \\
\hline 8 & $50-54$ & 40,9 & \\
\hline 9 & $55-59$ & 40 & \\
\hline
\end{tabular}

Sumber : Asosiasi Pengguna Jasa Internet Indonesia, 2018 
Menurut data Badan Pusat Statistik (BPS), jumlah penduduk Indonesia usia 20 tahun hingga 40 tahun di tahun 2020 diduga sekitar $34 \%$ dari total penduduk Indonesia yang mencapai 271 juta jiwa. Proporsi tersebut lebih besar dari proporsi generasi X (Gen-X) sebesar $20 \%$. Tahun 2020 generasi Millennial (Gen-Y) berada pada rentang usia 20 tahun hingga 40 tahun. Usia tersebut adalah usia produktif yang akan menjadi tulang punggung perekenomian Indonesia (Alvara Research, 2019).

Dalam industri pariwisata, revolusi industri 4.0 ini juga memberi dampak yang teramat besar baik bagi para pelaku usaha yang mencakup destinasi wisata, transportasi wisata, akomodasi, maupun berbagai sarana pendukung pariwisata lainnya seperti usaha jasa perjalanan wisata, dan tempat makan. Salah satu faktor penting yang berpengaruh terhadap usaha pariwisata pada era ini adalah terjadinya perubahan atau pergeseran perilaku dari para wisatawan dibandingkan di era sebelumnya.

Dalam strategi pemasaran, segmentasi pasar merupakan aspek penting untuk memilah pasar yang sangat besar menjadi beberapa kelompok berdasarkan kriteria tertentu, agar mempermudah dalam menentukan target pasar yang akan dituju (Kotler, Bowen \& Makens, 2014). Untuk itu para praktisi pemasaran perlu memahami berbagai hal yang berhubungan dan dapat memengaruhi perilaku masing-masing segmen pasar tersebut dalam memutuskan pembelian termasuk dalam berwisata.

Beberapa kajian dan teori menyatakan berbagai faktor yang memengaruhi perilaku wisatawan dalam memutuskan pembelian di antaranya faktor eksternal yaitu stimulus pemasaran (Soeswoyo, D.M. \& Nurmawanti, 2016), dan juga faktor internal atau karakteristik konsumen seperti faktor Pribadi dan Psikologis (Kotler, Bowen \& Makens, 2013). Beberapa aspek internal yang cukup berpengaruh terhadap perilaku wisatawan di antaranya adalah gender, penghasilan, tingkat pendidikan, kelas sosial dan usia. Menurut (Veiga at.al., 2017), kelompok usia millenial atau juga dikenal dengan Gen-Y telah menyebabkan perubahan terbesar dalam fungsi sektor pariwisata di dunia.

United Nations World Tourism Organizaion (UNWTO) bekerjasama dengan World Youth Student \& Educational (WYSE) mengungkapkan dalam buku hasil laporan penelitiannya, bahwa generasi muda yang melakukan perjalanan merupakan segmen pasar yang sangat potensial dan amat pesat perkembangannya bagi pariwisata, mengingat usianya yang cukup belia, diyakini kedepannya akan menjadi generasi yang sangat potensial bagi pariwisata. Saat ini jumlah youth traveller sudah mencapai $23 \%$ dari total wisatawan internasional setiap tahunnya, dan diyakini mampu memacu usaha pariwisata lokal, membantu penyebaran pariwisata ke berbagai area baru, dan juga menciptakan inovasi (UNWTO, 2016).

Cukup banyak penelitian sebelumnya yang mengkaji tentang Generasi Millenial, seperti penelitian yang mengkaji tentang motivasi dan preferensi aktivitas wisata Generasi Millenial di United States dan United Kingdom (Paulo Rita, Ana Brochado, \& Yublena Dimova, 2018), penelitian UNWTO bekerjasama dengan WYSE Travel Confederation (2016) tentang pengaruh atau kekuatan youth traveller, kajian untuk memahami pengalaman berwisata para Millenial di Belanda (Elena Cavagnaro, Simona Staffieri, \& Albert Postma, 2018), ataupun penelitian meta-analisis yang menelaah perilaku berwisata Generasi Millenial di Era Informasi Digital (Starĉević \& Konjikušić, 2018).

Kajian tentang Generasi Millenial masih menjadi topik yang menarik di mana-mana, khususnya yang berkaitan dengan pariwisata. Tidak diragukan lagi bahwa dalam beberapa tahun ke depan, Generasi Millennial akan menjadi konsumen utama dalam berbagai industri 
termasuk industri pariwisata karena diyakini mereka memiliki ketertarikan yang tinggi dalam berpergian ke luar negeri ( Gardiner et al, 2014). Pendapat senada juga ditegaskan oleh (Freed, 2015) dalam (UNWTO , 2016) yang menegaskan bahwa umumnya wisatawan usia muda senang melihat dunia dan mereka gemar menabung untuk memenuhi kebutuhannya tersebut.

Di Indonesia, sedikit sekali penelitian yang mengkaji tentang perilaku berwisata berdasarkan generasi di era revolusi industri 4.0. Penelitian tentang pariwisata Bali di era 4.0. ditelaah oleh (Bhaskara, 2017) dan ada juga penelitian tentang perilaku berwisata Generasi Millenial di Jakarta oleh (Wiweka, Wachyuni, Rini, Adnyana, \& Adnyana, 2019), namun belum ada penelitian yang mengkaji lebih jauh perbedaan Generasi Millenial dan generasi lainnya dalam perilaku berwisata.

Penelitian ini bertujuan untuk melakukan studi komparasi antara Generasi Millenial (Gen-Y) dan generasi sebelumnya yaitu Gen-X dalam perilaku berwisata sehingga diketahui apa saja persamaan dan perbedaannya. Kajian ini sangat menarik dilakukan untuk lebih memahami karakteristik dan perilaku berwisata antara kedua generasi tersebut khususnya untuk studi kasus wisatawan nusantara yang pernah berkunjung ke Kota Bogor. Hasil dari penelitian ini dapat membantu penyusunan strategi pemasaran bagi beberapa destinasi wisata, para pengusaha pendukung pariwisata, pemerintah daerah dan pihak-pihak lain yang berkepentingan dalam menarik segmen pasar dari kedua generasi tersebut. Pada kesempatana ini Peneliti mengucapkan terima kasih kepada Kementrian Riset, Teknologi dan Pendidikan Tinggi Republik Indonesia yang telah memberikan pengarahan untuk teknik penulisan karya ilmiah yang baik.

\section{Revolusi Industri 4.0}

Menurut (Ristekdikti, 2018), era revolusi industri 4.0. merupakan era yang menekankan pada pola digital economy, artificial intelligence, big data, robotic, dan lain sebagainya atau dikenal dengan fenomena disruptive. Istilah Revolusi Industri 4.0 dicetuskan pertama kali tahun 2011 oleh beberapa pakar asli Jerman, yang kemudian dikenalkan pada acara World Economic Forum (WEF) oleh Angella Markel pada tahun 2015. Semenjak itu berbagai negara besar seperti Jerman dan Amerika mulai melakukan penelitian serius untuk memajukan cara berpikir di balik Revolusi Industri 4.0. Era Revolusi Industri 4.0 merupakan kelanjutan dan inovasi dari era Revolusi Industri 3.0 yang memadukan inovasi di bidang Elektronik dan Teknologi Informasi. Revolusi Industri 4.0 merupakan era penerapan konsep otomatisasi oleh mesin tanpa memerlukan tenaga manusia. Hal tersebut sangat penting dan memberi dampak besar bagi siapapun karena dapat meningkatkan efisiensi waktu, sumber daya manusia, dan tentunya biaya. Pada era ini, melalui jaringan internet semua jenis arus perpindahan data dapat dilakukan real-time. Sehingga berbagai proses produksi dan administrasi dapat berjalan tanpa halangan apapun selama terhubung dengan internet.

Pada era Revolusi Industri 4.0 terdapat banyak inovasi baru, diantaranya Internet of Things (IoT), Big Data, percetakan 3D, Artifical Intelligence (AI), kendaraan tanpa pengemudi, rekayasa genetika, robot dan mesin pintar. Salah satu hal terbesar dalam Revolusi Industri 4.0 adalah Internet of Things (IoT) yang memiliki kemampuan dalam menyambungkan dan memudahkan proses komunikasi antara mesin, perangkat, sensor, dan manusia melalui jaringan internet. Big data adalah seluruh informasi yang tersimpan di cloud computing untuk membantu deteksi dini terjadinya kesalahan sehingga memungkinkan pencegahan atau peningkatan produktifitas dan kualitas suatu produk berdasarkan data yang terekam. Hal ini dapat terjadi karena adanya analisis data besar dengan sistem connection, cyber, content/context, community, dan customization (Binus University Knowledge Management \& Innovation, 2019). 


\section{Generasi X dan Y}

Menurut Gursoy at.al. dalam (Benckendorff, Moscardo \& Pendergast, 2010), yang dimaksud generasi adalah kelompok orang yang lahir pada periode waktu yang sama dan mengalami sejarah penting atau peristiwa kehidupan sosial yang sama. Menurut (Wiweka, 2019), penelitian khusus tentang perkembangan generasi terus ditelaah di antaranya oleh Lancaster dan Stillman (2002), Oblinger dan Oblinger (2005), Reeves dan Oh (2008). Para ahli tersebut mengelompokan masing-masing generasi dalam kurun waktu yang berbeda sesuai dengan klasifikasinya. Penelitian ini dibuat berdasarkan teori (Reeves dan Oh, 2008) yang juga diperkuat dengan teori (Campo, Haggerty, Haney \& Nippel, 2011) dalam Adi \& Indrawati (2019), yang membagi kriteria generasi menjadi beberapa kelompok yaitu : Mature Generation yang lahir pada era 1924-1945; Boom Generation yang lahir pada era setelah perang dunia-2 (1946-1964); Gen-X (lahir tahun 1965-1980); Gen-Y atau Millennial Generation (lahir tahun 1981- 2000) dan Gen-Z (lahir tahun 2001-saat ini).

Gen-X (1965-1980) adalah anak dari generasi sebelumnya yaitu Generasi Boomer. Mereka sudah mulai modern karena teknologi sudah mulai berkembang. Generasi ini adalah generasi transisi karena pada tahun 1960 hingga 1980 merupakan transisi ke teknologi yang lebih modern. Sedangkan Gen-Y (1981-2000) merupakan generasi yang unik di mana dalam pertumbuhannya sudah mengenal Internet of Things (IoT) sehingga banyak dipengaruhi oleh munculnya smartphone dan jejaring sosial (social media).

\section{Perilaku Konsumen (Consumer Behaviour)}

Menurut (Engel, Blackwell, \& Miniard, 1995) dalam Cohen, Prayag \& Moital (2014), perilaku konsumen merupakan semua kegiatan yang terlibat secara langsung dalam proses mendapatkan, mengkonsumsi, dan paska mengkonsumsi. Dipaparkan oleh (Kotler, Bowen \& Makens, 2014), bahwa perilaku konsumen dalam pembelian mencakup semua aktifitas mulai dari memahami apa yang dibutuhkan, mencari informasi, melakukan evaluasi atas berbagai alternatif, melakukan keputusan pembelian termasuk juga paska pembelian. Perilaku pembelian konsumen dipengaruhi oleh berbagai faktor dari luar seperti marketing stimuli, ekonomi, teknologi dan lainnya, dan juga faktor dari dalam diri konsumen yang disebut larakteristik konsumen. Contoh Karakteristik konsumen di antaranya faktor Pribadi seperti gender, usia, pekerjaaan, gaya hidup, dan faktor Psikologis konsumen seperti motivasi, persepsi, proses belajar.

Menurut (Cohen et.al., 2014), perilaku konsumen dalam proses membeli suatu produk atau jasa dapat dijabarkan ke dalam beberapa tahap. Menurutnya, perilaku konsumen dalam proses membuat keputusan untuk melakukan perjalanan dibagi dalam tahap Initiation, information search, assesment, final decision, during travel, dan post travel. Tahapan konsep kajian ini diuraikan dalam Gambar 1 berikut: 


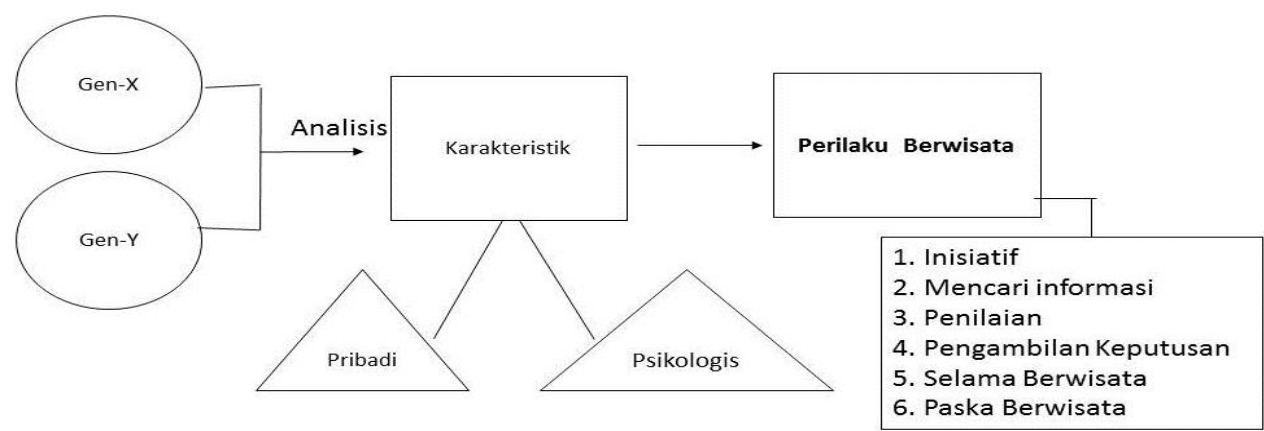

Gambar 1. Kerangka Konseptual Penelitian

(Kotler, Bowen \& Makens, 2013 dan Cohen, 2014)

\section{METODOLOGI}

Penelitian ini menggunakan pendekatan survey kepada wisatawan yang pernah berkunjung ke Kota Bogor pada bulan Februari 2020. Teknik pengumpulan data dilakukan dengan melakukan kajian literatur dari beberapa jurnal, buku, artikel ataupun referensi lain yang relevan, kemudian melakukan penyebaran kuesioner dan wawancara. Penyebaran kuesioner dilakukan secara daring dan juga disebarkan langsung di Kebun Raya Bogor dan juga tempat pembelian oleh-oleh khas Bogor yaitu Lapis Talas Sangkuriang dengan kriteria tertentu, yaitu usia Gen-X dan Gen-Y, pernah berwisata ke Kota Bogor, dan juga memiliki gadget. Sampel responden yang dikaji dalam penelitian ini diambil dari 162 Gen-X dan 244 Gen-Y yang dipilih sesuai dengan kriteria penelitian. Sebelum proses penyebaran kuesioner kepada seluruh Responden, peneliti melakukan test kepada 3 calon responden dari Gen-X dan 3 calon responden dari Gen-Y yang fungsinya untuk penyempurnaan.

Pengumpulan data melalui wawancara perlu dilakukan kepada beberapa responden baik dari Gen-X maupun Gen-Y, untuk mendapat gambaran yang lebih jelas dan informasi yang lebih mendalam untuk membahas hasil survey. Teknik wawancara dilakukan secara tatap muka langsung maupun daring melalui WhatsApp call atau Chat.

Data terkumpul kemudian dianalisis secara deskriptif dengan mencari nilai persentasi atas semua pertanyaan. Pertanyaan dibagi dalam 2 bagian yaitu Profil Karakteristik Responden berdasarkan teori (Kotler, Bowen \& Makens, 2013) dan Perilaku Berwisata para Responden. Pertanyaan Perilaku Berwisata Responden dimulai dari tahap Inisiasi, Pencarian informasi, Penilaian, Keputusan Pembelian, Perilaku Ketika Berwisata dan Paska Berwisata, berdasarkan teori (Cohen, 2014).

Analisis data dilakukan secara kualitatif, dimana data terkumpul diklasifikasikan, direduksi dan dipaparkan secara jelas untuk kemudian ditarik kesimpulan (Miles, Huberman \& Sadana, 2014). Validasi data dilakukan secara triangulasi sumber (kajian pustaka, kuesioner dan wawancara).

\section{HASIL DAN PEMBAHASAN}

\section{Profil, Karakteristik Gen-X dan Gen-Y (Millenial)}

Responden yang dijadikan sampel dalam kajian ini terdiri dari dua generasi yaitu GenX kelahiran 1965-1980 (usia 40-55 tahun), dan Gen-Y atau Generasi Millenial kelahiran 1981- 
2000 ( usia 20-39 tahun). Jumlah seluruh sampel adalah 406 terdiri dari 203 Gen-X dan 244 Gen Y. Tabel 2 berikut memaparkan data demografi dan geografi responden :

Tabel 2.

\begin{tabular}{|l|c|c|}
\hline \multicolumn{1}{|c|}{ Kriteria } & Gen-X (\%) & Gen-Y (\%) \\
\hline Gatget Digunakan & & 98 \\
\hline Smartphone & 99 & 33 \\
\hline Laptop & 31 & 9 \\
\hline P. C. & 6 & 7 \\
\hline Tablet & 5 & 98 \\
\hline Gatget Terkoneksi Internet & 99 & 1 \\
\hline Terkoneksi & 1 & 80 \\
\hline Tidak Terkoneksi & 78 & 55 \\
\hline Aktivitas Penggunaan Gadget & 69 & 37 \\
\hline Media Sosial & 52 & 38 \\
\hline Berita Terkini & 38 & 41 \\
\hline E-mail & 32 & \\
\hline Rencana Liburan & & \\
\hline Fashion, Edukasi, Gosip & & \\
\hline
\end{tabular}

\section{Profil Demografi \& Geografi Responden}

Untuk mengetahui lebih jauh kriteria penggunaan gadget para responden, diuraikan dalam Tabel 3 berikut :

Tabel 3.

Kriteria Penggunaan Gadget Responden

\begin{tabular}{|c|l|c|c|}
\hline Kriteria & \multicolumn{1}{|c|}{$\begin{array}{c}\text { Gen-X } \\
\text { (Lahir 1965-1980) } \\
(\%)\end{array}$} & $\begin{array}{c}\text { Gen-Y } \\
\text { (Lahir 1981-2000) } \\
(\%)\end{array}$ \\
\hline Gender & Wanita & 64 & 62 \\
\hline & Pria & 36 & 38 \\
\hline Pekerjaann & Mahasiswa/Pelajar & - & 44 \\
\hline & Karyawan & 37 & 43 \\
\hline & Profesional/ Ahli & 22 & 6 \\
\hline & Pengusaha & 16 & 6 \\
\hline & ASN & 14 & - \\
\hline & Ibu Rumah Tangga & 11 & 1 \\
\hline Status & Menikah & 90 & 73 \\
\hline & Belum/Pernah Menikah & 10 & 36 \\
\hline Domisili & Bogor & 28 & 35 \\
\hline & Jakarta & 22 & 29 \\
\hline & Depok/Tangerang/Serang/ & 31 & - \\
\hline & Bandung/Bekasi & 18 & \\
\hline & Jawa Tengah \& Luar Jawa & & \\
\hline
\end{tabular}




\begin{tabular}{|l|c|c|}
\hline Media Sosial yang Digunakan & & \\
\hline Instagram & 45 & 87 \\
\hline Facebook & 45 & 29 \\
\hline Youtube & 32 & 60 \\
\hline Twitter & 11 & 26 \\
\hline Line & 9 & 26 \\
\hline WhatssApp & 7 & 10 \\
\hline Durasi Penggunaan Gadget/ Hari & & \\
\hline 1-5 Jam & 48 & 34 \\
\hline 6-10 jam & 38 & 41 \\
\hline 11-15 jam & 14 & 19 \\
\hline >16 Jam & - & 11 \\
\hline
\end{tabular}

Tabel 4 berikut menggambarkan hasil penilaian responden Gen-X dan Gen-Y dalam hal preferensi dan motivasi berlibur :

Tabel 4.

Preferensi dan Motivasi Berlibur Responden

\begin{tabular}{|l|c|c|}
\hline \multicolumn{1}{|c|}{ Kriteria } & Gen-X (\%) & Gen-Y (\%) \\
\hline Tempat Favorit Berlibur & 80 (Yogya, Bali,Sumatera, NTT) & $\begin{array}{c}84 \text { (Bandung, Yogya, Bali, } \\
\text { Belitung) }\end{array}$ \\
\hline Dalam Negeri & $\begin{array}{c}\text { 52 (Asia, AS) } \\
\text { Maldives) }\end{array}$ & 14 \\
\hline Luar Negeri & 11 & 18 \\
\hline Dalam Kota & 19 & 20 \\
\hline Anggaran Liburan & 20 & 36 \\
\hline$<$ 1 Juta & 20 & 34 \\
\hline 1-2 Juta & 47 & 84 \\
\hline 2,5-5 Jt & & 19 \\
\hline$>5$ Jt & 80 & 26 \\
\hline Sumber Dana Berlibur & 20 & 10 \\
\hline Tabungan & 2 & 31 \\
\hline Passive Income & & 62 \\
\hline Keluarga & 2 & \\
\hline Frekuensi Berlibur & 70 & 74 \\
\hline 1x setiap bulan & 28 & 65 \\
\hline 1-2 x setahun & & 13 \\
\hline 3-6 x setahun & 85 & 22 \\
\hline Rekan Favorit Berwisata & 41 & \\
\hline Keluarga/ Saudara & 11 & \\
\hline Teman & 11 & \\
\hline Komunitas & & \\
\hline Rombongan Biro Perjalanan & & \\
\hline Motivasi Berwisata & & \\
\hline
\end{tabular}




\begin{tabular}{|l|c|c|}
\hline $\begin{array}{l}\text { Keluar dari Rutinitas Sehari- } \\
\text { hari }\end{array}$ & 67 & 66 \\
\hline Cari Pengalaman Baru & 44 & 56 \\
\hline Tertarik Wisata Alam & 37 & 42 \\
\hline
\end{tabular}
Gen-Y:

Tabel 5 berikut menggambarkan perbandingan perilaku berwisata antara Gen-X dan

Tabel 5.

Perilaku Berwisata Generasi-X dan Generasi-Y

\begin{tabular}{|c|c|c|}
\hline Aspek & $\begin{array}{c}\text { Gen-X } \\
\text { ( Lahir 1965-1980/ } \\
\text { usia 40-55 thn) } \\
\text { n=162 }\end{array}$ & $\begin{array}{l}\text { Gen-Y/ Millenial } \\
\text { (Lahir 1981-2000/ } \\
\text { usia 20-39 thn) } \\
\quad \text { n=244 }\end{array}$ \\
\hline $\begin{array}{l}\text { Proses PengambilanKeputusan } \\
\text { Inisiasi }\end{array}$ & & \\
\hline $\begin{array}{l}\text { Waktu yang diperlukan untuk } \\
\text { perencanaan berwisata: }\end{array}$ & $\begin{array}{l}51 \% \text { lebih dari } 1 \text { bulan, } 26 \% \\
\text { perlu waktu } 3-7 \text { hari, } 22 \% \\
\text { membutuhkan } 2-4 \text { minggu } \\
\text { dan } 15 \% \text { memerlukan } \\
\text { kurang dari } 3 \text { hari }\end{array}$ & $\begin{array}{l}54 \% \text { lebih dari } 1 \text { bulan, } 22 \% \\
\text { perlu waktu } 3-7 \text { hari, } 20 \% \\
\text { membutuhkan } 2-4 \text { minggu } \\
\text { dan } 17 \% \text { memerlukan } \\
\text { kurang dari } 3 \text { hari }\end{array}$ \\
\hline $\begin{array}{l}\text { Faktor yang berpengaruh } \\
\text { dalam penentuan destinasi } \\
\text { wisata: }\end{array}$ & $\begin{array}{l}72 \% \text { karena rasa ingin tahu } \\
\text { yang tinggi, } 40 \% \\
\text { terpengaruh publikasi pada } \\
\text { media sosial, } 14 \% \text { karena } \\
\text { ikut tren yang berkembang, } \\
12 \% \text { karena ulasan pada } \\
\text { Blog. }\end{array}$ & $\begin{array}{l}70 \% \text { akibat rasa ingin tahu } \\
\text { yang tinggi, } 44 \% \text { karena } \\
\text { publikasi pada media sosial., } \\
25 \% \text { ulasan pada Blog dan } \\
23 \% \text { Ikut tren yang } \\
\text { berkembang. }\end{array}$ \\
\hline $\begin{array}{l}\text { Rating pada tujuan wisata } \\
\text { yang akan dikunjungi }\end{array}$ & $\begin{array}{l}\text { Sangat berpengaruh } 70 \% \text {, } \\
\text { tidak berpengaruh } 30 \%\end{array}$ & $\begin{array}{l}\text { Sangat berpengaruh } 82 \% \text {, } \\
\text { tidak berpengaruh } 18 \%\end{array}$ \\
\hline $\begin{array}{l}\text { Media yang digunakan dalam } \\
\text { melihat rating kualitas tujuan } \\
\text { wisata: }\end{array}$ & $\begin{array}{l}\text { Trip Advisor } 63 \% \text {, } \\
\text { Instagram 51\%, TV 23\%, } \\
\text { dan Majalah Wisata } 14 \%\end{array}$ & $\begin{array}{l}82 \% \text { Instagram, 53\% Trip } \\
\text { Advisor, 22\% TV dan } 8 \% \\
\text { Majalah Wisata. }\end{array}$ \\
\hline $\begin{array}{l}\text { Rekomendasi, komentar, dan } \\
\text { keluhan, berpengaruh dalam } \\
\text { menentukan tujuan wisata: }\end{array}$ & $\begin{array}{l}93 \text { berpengaruh dan } \\
7 \% \text { tidak berpengaruh }\end{array}$ & $\begin{array}{l}90 \text { berpengaruh dan } \\
10 \% \text { tidak berpengaruh }\end{array}$ \\
\hline Mencari Informasi & & \\
\hline
\end{tabular}




\begin{tabular}{|c|c|c|}
\hline $\begin{array}{l}\text { Media apa yang digunakan } \\
\text { dalam mencari informasi } \\
\text { tentang destinasi yang ingin } \\
\text { dikunjungi : }\end{array}$ & $\begin{array}{c}75 \% \text { Media sosial, google } \\
58 \% \text {, informasi langsung } \\
\text { dari keluarga/teman }(54 \%) \\
\text {, website resmi }(48 \%) .\end{array}$ & $\begin{array}{c}85 \% \text { Media sosial, google } \\
65 \% \text {, informasi langsung } \\
\text { dari keluarga/teman }(46 \%), \\
\text { website resmi }(47 \%)\end{array}$ \\
\hline \multicolumn{3}{|l|}{ Penilaian } \\
\hline $\begin{array}{l}\text { Konten yang disukai dalam } \\
\text { mencari informasi wisata : }\end{array}$ & $\begin{array}{l}72 \% \text { Banyak } \\
\text { banyak deskripsi, vambar } \\
\text { vlog }(49 \%) \text { dan } \\
\text { gambar sedikit deskripsi } \\
(27 \%) .\end{array}$ & $\begin{array}{l}\text { 66\% Banyak gambar banyak } \\
\text { deskripsi, Video/vlog }(65 \%) \\
\text { dan Banyak gambar sedikit } \\
\text { deskripsi }(25 \%) .\end{array}$ \\
\hline $\begin{array}{l}\text { Faktor yang dipertimbangkan } \\
\text { sebelum menentukan untuk } \\
\text { berwisata }\end{array}$ & $\begin{array}{l}83 \% \text { Budget, } \\
65 \% \text { waktu luang, } \\
27 \% \text { Butuh refreshing }\end{array}$ & $\begin{array}{l}\text { 84\% Budget, } \\
74 \% \text { waktu luang, } \\
32 \% \text { Butuh refreshing }\end{array}$ \\
\hline $\begin{array}{l}\text { Dilakukan perbandingan } \\
\text { sebelum melakukan pemesan- } \\
\text { an untuk jasa tranportasi/ } \\
\text { akomodasi/ paket wisata: }\end{array}$ & $\begin{array}{l}99 \% \text { Ya } \\
1 \% \text { Tidak }\end{array}$ & $\begin{array}{l}99 \% \text { Ya } \\
1 \% \text { Tidak }\end{array}$ \\
\hline Faktor yang dibandingkan & $\begin{array}{l}\text { 86\% Harga, 74\% Kualitas, } \\
67 \% \text { Fasilitas, } \\
\text { 54\% Promosi Khusus }\end{array}$ & $\begin{array}{l}\text { 88\% Harga, 71\% Kualitas, } \\
\text { 71\% Fasilitas, } \\
\text { 56\% Promosi Khusus }\end{array}$ \\
\hline $\begin{array}{l}\text { Dalam melakukan perjalanan } \\
\text { wisata, faktor pendukung } \\
\text { lainnya yang dipertimbangkan } \\
:\end{array}$ & $\begin{array}{l}86 \% \quad \text { Keamanan, } 63 \% \\
\text { Iklim, , 37\%, Budaya lokal, } \\
21 \% \\
\text { lingkungan }\end{array}$ & $\begin{array}{l}\text { 79\% Keamanan, 72\% Iklim, } \\
43 \% \text { Budaya lokal, } \\
\text { 33\% Kelestarian lingkungan }\end{array}$ \\
\hline Pengambilan Keputusan & & \\
\hline $\begin{array}{l}\text { Online Travel Agent atau } \\
\text { sarana yang paling sering } \\
\text { digunakan untuk pemesanan } \\
\text { transportasi pariwisata: }\end{array}$ & $\begin{array}{l}\text { Traveloka } 75 \% \text {, tiket.com } \\
32 \% \text {, website resmi } 27 \% \text {, } \\
\text { pegi-pegi } 21 \%\end{array}$ & $\begin{array}{l}\text { Traveloka } 84 \% \text {, tiket.com } \\
40 \% \text {, website resmi } 21 \% \text {, } \\
\text { pegi-pegi } 16 \% \text {, lainnya } 10 \%\end{array}$ \\
\hline $\begin{array}{l}\text { Online Travel Agent atau } \\
\text { sarana yang paling sering } \\
\text { digunakan untuk pemesanan } \\
\text { akomodasi pariwisata }\end{array}$ & $\begin{array}{l}\text { 68\% Traveloka, } \\
28 \% \text { Website resmi, } \\
26 \% \text { Agoda, } 17 \% \text { Air BNB }\end{array}$ & $\begin{array}{l}86 \% \text { Traveloka, } \\
\text { 22\% AirBNB, 17\% Agoda } \\
\text { dan } 17 \% \text { Website resmi }\end{array}$ \\
\hline
\end{tabular}




\begin{tabular}{|c|c|c|}
\hline $\begin{array}{l}\text { Online Travel Agent atau } \\
\text { sarana yang paling sering } \\
\text { digunakan untuk pemesanan } \\
\text { paket wisata /tiket masuk/ } \\
\text { tiket pertunjukan: }\end{array}$ & $\begin{array}{l}\text { Traveloka } 68 \% \text {, tiket.com } \\
28 \% \text {, website resmi } 27 \% \text {, } \\
\text { Trip Advisor } 10 \%\end{array}$ & $\begin{array}{l}\text { Traveloka } 72 \% \text {, tiket.com } 31 \\
\% \text {, website resmi } 31 \% \text {, Trip } \\
\text { Advisor } 7 \%\end{array}$ \\
\hline $\begin{array}{l}\text { Alat pembayaran yang paling } \\
\text { sering digunakan keperluan } \\
\text { berwisata: }\end{array}$ & $\begin{array}{l}\text { Internet Banking } 59 \% \text {, } \\
\text { Kartu Kredit 44\%, Cash } \\
38 \% \text { dan } 9 \% \text { melalui Mini } \\
\text { Market (Alfa/Indomaret) }\end{array}$ & $\begin{array}{l}\text { Internet Banking } 70 \% \text {, Cash } \\
48 \% \text {, Kartu Kredit } 31 \% \text { dan } \\
11 \% \text { Lewat Mini Market } \\
\text { (Alfa/Indomaret) }\end{array}$ \\
\hline \multicolumn{3}{|l|}{ Selama Berwisata } \\
\hline $\begin{array}{l}\text { Perillaku berwisata yang } \\
\text { paling disenangi : }\end{array}$ & $\begin{array}{l}\text { 84\% Berwisata bersama } \\
\text { keluarga secara mandiri, } \\
38 \% \text { Berwisata bersama } \\
\text { teman/ komunitas secara } \\
\text { mandiri, 19\% Berwisata } \\
\text { secara backpacker, dan } \\
\text { 16\% Berwisata ke tempat } \\
\text { yang sudah dikenal melalui } \\
\text { travel agent }\end{array}$ & $\begin{array}{c}\text { 61\% Berwisata bersama } \\
\text { keluarga secara mandiri, } \\
54 \% \text { Berwisata bersama } \\
\text { teman/ komunitas secara } \\
\text { mandiri. } 39 \% \text { Berwisata } \\
\text { secara backpacker, } 13 \% \\
\text { Berwisata ke tempat yang } \\
\text { sudah dikenal melalui travel } \\
\text { agent, }\end{array}$ \\
\hline $\begin{array}{l}\text { Transportasi berwisata yang } \\
\text { paling sering digunakan ke } \\
\text { tujuan wisata : }\end{array}$ & $\begin{array}{l}\text { 68\% Transportasi Darat } \\
\text { ( mobil/bis/motor), 68\% } \\
\text { Pesawat, 30\% Kereta api. }\end{array}$ & $\begin{array}{l}69 \% \text { Transportasi Darat ( } \\
\text { mobil/bis/motor), } 61 \% \\
\text { Pesawat, 37\% Kereta api, }\end{array}$ \\
\hline $\begin{array}{l}\text { Transportasi yang paling } \\
\text { sering digunakan selama } \\
\text { berwisata: }\end{array}$ & $\begin{array}{l}\text { car rental } 48 \% \text {, online } \\
\text { transportation } 42 \%, \\
\text { kendaraan pribadi } 41 \%\end{array}$ & $\begin{array}{l}\text { car rental } 48 \%, \text { online } \\
\text { transportation } 43 \%, \\
\text { kendaraan pribadi } 45 \%\end{array}$ \\
\hline $\begin{array}{l}\text { Pilihan utama akomodasi } \\
\text { selama berwisata: }\end{array}$ & $\begin{array}{c}\text { Hotel Berbintang 59\%, } \\
\text { Homestay/Pondok Wisata } \\
\text { 43\%, Penginapan Non } \\
\text { Bintang } 20 \% \text {, dan } 10 \% \text { di } \\
\text { Rumah keluarga/ }\end{array}$ & $\begin{array}{c}\text { Homestay/Pondok Wisata } \\
55 \% \text {, Hotel Berbintang } \\
52 \% \text {, Rumah } \\
\text { keluarga/teman } 25 \% \\
\text { Penginapan Non Bintang } \\
23 \%\end{array}$ \\
\hline $\begin{array}{l}\text { Sarana yang paling sering } \\
\text { digunakan untuk mencari } \\
\text { lokasi wisata: }\end{array}$ & $\begin{array}{lr}\text { Google maps } 90 \%, & \text { Waze } \\
31 \% \text {, Bertanya } & \text { ke } \\
\text { masyarakat } 25 \%, & \text { Peta } \\
\text { manual } 14 \% & \end{array}$ & $\begin{array}{l}\text { Google maps } 89 \% \text {, Waze } \\
32 \% \text {, Bertanya ke } \\
\text { masyarakat } 30 \%, \\
\text { Peta manual } 3 \%,\end{array}$ \\
\hline
\end{tabular}




\begin{tabular}{|c|c|c|}
\hline $\begin{array}{l}\text { Faktor yang paling } \\
\text { menentukan dalam memilih } \\
\text { tempat makan selama } \\
\text { berwisata: }\end{array}$ & $\begin{array}{c}\text { Tampilan dan kebersihan } \\
70 \% \text {, Lokasi } 64 \% \text {, Harga } \\
52 \%\end{array}$ & $\begin{array}{c}\text { Harga } 70 \% \text {, Tampilan dan } \\
\text { kebersihan } 70 \% \text {, Lokasi } \\
59 \%\end{array}$ \\
\hline $\begin{array}{l}\text { Jenis tempat makan yang } \\
\text { disukai selama berwisata }\end{array}$ & $\begin{array}{l}90 \% \text { Tempat makan khas } \\
\text { daerah, } 26 \% \text { Tempat } \\
\text { makan yang murah, } \\
\text { restoran cepat saji } 20 \%, \backslash \\
15 \% \text { Cafe/Restoran besar }\end{array}$ & $\begin{array}{c}\text { 95\% Tempat makan yang } \\
\text { murah, } 84 \% \text { Tempat makan } \\
\text { khas daerah, } 30 \% \text { Restoran } \\
\text { cepat saji, } \\
\text { 18\% Cafe/Restoran besar }\end{array}$ \\
\hline \multicolumn{3}{|l|}{ Paska Berwisata } \\
\hline $\begin{array}{l}\text { Aktivitas yang paling sering } \\
\text { dilakukan setelah menikmati } \\
\text { produk atau jasa wisata : }\end{array}$ & $\begin{array}{l}79 \% \text { Upload photo di } \\
\text { sosial media, } 28 \% \text { Tulis } \\
\text { komentar di media sosial, } \\
17 \% \text { Memberi Tip lalu } \\
\text { 14\% Tulis komentar di } \\
\text { website resmi }\end{array}$ & $\begin{array}{l}\text { 82\% Upload photo di sosial } \\
\text { media, } 25 \% \text { Memberi Tip, } \\
\text { 13\% Tulis komentar di } \\
\text { media sosial, } 11 \% \text { Tulis } \\
\text { komentar di website resmi }\end{array}$ \\
\hline $\begin{array}{l}\text { Media yang digunakan untuk } \\
\text { berbagi pengalaman } \\
\text { berwisata }\end{array}$ & $\begin{array}{c}70 \% \text { Instagram, } 65 \% \text { Face } \\
\text { Book, 14\% Trip Advisor, } \\
7 \% \text { Twitter, } 5 \% \text { Line }\end{array}$ & $\begin{array}{c}\text { 93\% Instagram, } 26 \% \text { Face } \\
\text { Book, 17\% Twitter, 15\% } \\
\text { Line, } 4 \% \text { Trip Advisor }\end{array}$ \\
\hline
\end{tabular}

\section{Pembahasan}

\section{Karaktersitik Gen-X dan Gen-Y (Millenial)}

Rentang usia Gen-X yaitu 35-55 merupakan usia produktif sehingga mayoritas responden $(89 \%)$ sudah mempunyai penghasilan sendiri dan $11 \%$ berstatus ibu rumah tangga. Sedangkan rentang usia Gen-Y atau generasi Milenial adalah 20-34 dimana hampir setengahnya $44 \%$ adalah pelajar/mahasiswa, dan $49 \%$ executive muda, kemudian $6 \%$ pengusaha dan $1 \%$ ibu rumah tangga.

Karakteristik Gen-X dan Gen-Y dalam memiliki dan menggunakan gadget memiliki persamaan dimana 98-99 \% sudah menggunakan Gadget baik itu smartphone, Laptop, Personal computer (PC) ataupun Tablet. Hampir semua (99\%) kedua generasi tersebut mempunyai gardget lebih dari satu dan sudah terkoneksi dengan internet untuk berselancar di dunia maya. Hal tersebut mendukung hasil penelitian (Wiweka, 2019) yang menguraikan bahwa 99\% Generasi Millenial Jakarta mempunyai gadget lebih dari satu dan terkoneksi internet. Gadget utama yang dimiliki oleh Gen-X dan Gen-Y adalah smartphone karena ringan, fungsinya sangat efektif untuk berkomunikasi dan mudah dibawa kemanapun. Tidak dapat dipungkiri bahwa kedua generasi cukup mahir menggunakan berbagai aplikasi yang terdapat dalam smartphone. Persamaan lainnya adalah responden kedua generasi tersebut mayoritas memerlukan waktu lebih dari 1 bulan untuk perencanaan berwisata, karena menyangkut persiapan dana, pengaturan waktu luang, pemesanan transportasi, akomodasi yang perlu ditelaah lebih lanjut. Persamaan lainnya adalah mayoritas Gen-X dan Gen-Y menggunakan sumber dana dari tabungan, serta teman favorit untuk berwisata adalah keluarga atau saudara. 
Hal ini karena Gen-X mayoritas sudah berkeluarga dan cenderung untuk berwisata bersama keluarga sedangkan Gen-Y mayoritas belum berkeluarga sehingga masih bergantung kepada dana dan ijin dari keluarga. Baik Gen-X maupun Gen-Y mempunyai persamaan motivasi untuk berwisata yaitu mayoritas dari kedua generasi tersebut motivasinya untuk ke luar dari rutinitas sehari-hari. Hal tersebut karena Gen-X mayoritas adalah pekerja sehingga memerlukan refreshing di luar dunia kerja. Begitu pula dengan Gen-Y yang umumnya adalah mahasiswa dan pekerja, mereka perlu waktu besantai atau berwisata ketika libur kuliah atau di luar rutinitas kerja. Penggunaan Gadget untuk perencanaan liburan, Gen-X dan Gen-Y memilki persentasi yang sama yaitu $38 \%$.

Dari hasil survey, didapat beberapa perbedaan karakteristik kedua generasi tersebut yaitu mayoritas Gen-X menggunakan gadgetnya selama 1-5 jam perhari namun Gen-Y mayoritas menggunakan gadgetnya lebih lama yaitu 6-10 jam sehari. Walaupun Gen-X dan Gen-Y sama sama mayoritas menggunakan gadget untuk aktivitas media sosial (78-80\%) namun ada perbedaan preferensi jenis jejaring sosial yang digunakan antara kedua generasi tersebut, di mana mayoritas Gen-X menggunakan gadgetnya untuk Instagram (45\%) dan Facebook (45\%), kemudian Email (40\%), lalu Youtube, Twitter, Line dan WhatsApp. Gen-Y jauh lebih besar preferensi dalam menggunakan Instagram (87\%), kemudian Youtube (60\%), E-mail (43\%), lalu Facebook, Line, Twitter, WhatsApp. Mayoritas Gen-X membutuhkan dana liburan lebih dari 5 juta sedangkan Gen-Y mayoritas membutuhkan dana 2,5 - 5 juta untuk berwisata.

\section{Perilaku Berwisata Generasi-X dan Generasi-Y (Millenial)}

\section{Proses Pengambilan Keputusan Berwisata Inisiasi}

Persamaan Gen-X dan Gen-Y dalam aspek Inisiasi adalah mayoritas memerlukan waktu lebih dari 1 bulan dalam membuat perencanaan berwisata. Kedua generasi mayoritas terpengaruh oleh rating destinasi wisata yang akan dikunjungi, dan juga oleh rekomendasi, komentar dan keluhan dari para wisatawan ataupun teman yang telah mengunjungi destinasi tersebut. Faktor yang berpengaruh dalam penentuan destinasi wisata pada kedua generasi mayoritas karena karena rasa ingin tahu yang tinggi dan terpengaruh publikasi pada media sosial. Namun untuk Gen-X kemudian dipengaruhi faktor ikut tren yang berkembang, terakhir (12\%) karena ulasan pada Blog, sedangkan bagi Generasi Millenial faktor ulasan pada Blog lebih besar pengaruhnya dibanding faktor ikut tren yang berkembang. Sehingga Untuk Gen-Y, disamping faktor rasa ingin tahu yang besar faktor lainnya yang sangat berpengaruh adalah karena sangat mempercayai publikasi ataupun ulasan dari teman dan komunitas dari jejaring sosial dan blog. Perbedaan yang cukup signifikan pada aspek inisiasi kedua generasi tersebut adalah Gen-X mayoritas lebih menyukai menggunakan Trip Advisor dalam melihat rating kualitas tujuan wisata karena ulasan, rekomendasi dan keluhan dalam Trip Advisor dianggap lebih global sehingga lebih dipercaya. Gen-Y mayoritas lebih senang mempercayai jejaring sosial Instagram karena dianggap ulasan, rekomendasi dan keluhan berasal dari teman atau komunitas yang informasinya lebih bervariatif untuk melihat narasi, gambar-gambar maupun video.

\section{Mencari Informasi}

Baik Gen-X dan Gen-Y memiliki persamaan dalam mencari informasi untuk perencanaan berwisata, yaitu mayoritas menggunakan Media sosial, kemudian Google, lalu informasi langsung dari keluarga/teman dan kemudian dari Website resmi. Dari data tersebut, terlihat bahwa kedua generasi sangat bergantung pada informasi di media sosial. Hal tersebut senada dengan (Wiweka, 2019) yang melakukan penelitian pada generasi Millenial di Jakarta, 
dan mendukung penelitian Assenov dan Khurana dalam (Soeswoyo, Dewi \& Asparani, 2018) yang menyatakan bahwa banyak konsumen sekarang melihat media sosial sebagai sumber informasi yang paling dapat diandalkan daripada informasi yang berasal dari perusahaan.

\section{Penilaian}

Kedua generasi memilki persamaan dalam berbagai aspek Penilaian, yaitu dalam hal konten yang disukai dalam mencari informasi wisata dan Beberapa faktor yang dipertimbangkan serta dibandingkan sebelum menentukan untuk berwisata. Mayoritas Gen-X dan Gen-Y menyukai konten yang banyak gambar dan banyak deskripsi kemudian Video/Vlog. Sebelum menentukan pemesanan untuk jasa transportasi, akomodasi dan paket wisata, kedua generasi tersebut mayoritas melakukan perbandingan terlebih dahulu khususnya dalam hal harga, kualitas, fasilitas, kemudian penawaran khusus. Faktor lainnya yang dipertimbangkan oleh mayoritas Gen-X dan Gen-Y sebelum menentukan berwisata adalah faktor anggaran kemudian waktu luang dan butuh refreshing. Faktor pendukung lainnya yang dipertimbangkan mayoritas kedua generasi tersebut secara berurutan prioritasnya adalah keamanan/keselamatan, lalu iklim, budaya lokal dan kelestarian lingkungan. Hasil survey ini terdapat perbedaan dengan (Wiweka, 2019) yang mengungkapkan bahwa iklim merupakan faktor lain yang utama dipertimbangkan generasi Millenial Jakarta.

\section{Pengambilan Keputusan}

Dua hal persamaan Gen-X dan Gen-Y dalam aspek Pengambilan Keputusan adalah Online Travel Agent atau sarana yang paling sering digunakan untuk pemesanan transportasi pariwisata, mayoritas menggunakan Traveloka, kemudian Tiket.com, lalu Website resmi, dan Pegipegi. Sedangkan sarana yang paling sering digunakan untuk pemesanan paket tour /tiket masuk/ tiket pertunjukan, mayoritas menggunakan Traveloka, Tiket.com, Website resmi kemudian Trip Advisor. Hasil survey ini menunjukan bahwa Online Travel Agent (OTA) Traveloka.com paling mudah diingat dan dipercaya oleh Gen-X dan Gen-Y.

Perbedaan kedua generasi dalam aspek Pengambilan Keputusan adalah dalam sarana yang paling sering digunakan untuk pemesanan akomodasi pariwisata, dimana mayoritas Gen-X menggunakan Traveloka, lalu Website resmi, Agoda dan AirBNB, sedangkan Gen-Y mayoritas menggunakan Traveloka lalu AirBNB, kemudian Agoda dan Website resmi. Bagi Gen-X, Traveloka dijadikan sarana utama untuk melihat harga khusus yang ditawarkan namun kemudian lebih mempercayai Website Resmi untuk melihat beragam konten dari website hotel berbintang yang menjadi preferensinya seperti harga, kualitas dan fasilitasnya. Sedangkan mayoritas Gen-Y mempercayai Traveloka sebagai acuan utama promosi khusus, lalu lebih menyukai AirBNB dan Pegipegi daripada Website resmi, sesuai dengan karakteristik Millenial yang lebih menyukai akomodasi berbentuk Pondok Wisata atau Homestay ataupun akomodasi yang bisa sharing beramai-ramai. Hal lain yang berbeda dari kedua generasi tersebut adalah dalam hal alat pembayaran untk transaksi pariwisata, dimana Gen-X lebih menyukai membayar dengan Internet banking, lalu kartu kredit, kemudian Cash dan lewat minimaret. Mayoritas Gen-Y, disamping menggunakan alat pembayaran utama internet banking, kemudian lebih menyukai membayar dengan Cash, Kartu Kedit dan lewat mini market. Hal tersebut karena mayoritas Gen-X adalah usia produktif dan sudah stabil penghasilannya sehingga mayoritas mempunyai kartu kredit. Sedangkan Gen-Y disamping merupakan usia pelajar/mahasiswa, mayoritas adalah usia mulai bekerja sehingga belum banyak yang mempunyai kartu kredit. 


\section{Selama Berwisata}

Berdasarkan hasil penelitian ini, terdapat 4 hal persamaan Gen-X dan Gen-Y dalam Aspek Selama Berwisata, yaitu dalam hal Perillaku berwisata yang paling disenangi yaitu mayoritas suka berwisata bersama keluarga secara mandiri. Adapun Transportasi berwisata yang paling sering digunakan ke tujuan wisata adalah mayoitas menggunakan transportasi darat dan pesawat. Kedua generasi tersebut lebih menyukai Car rental dan kendaraan Online yang digunakan selama berwisata. Sarana yang paling sering digunakan untuk mencari lokasi destinasi wisata, mayoritas adalah Google maps, kemudian Waze, lalu Bertanya ke masyarakat, dan Peta manual.

Perbedaan Gen-X dan Gen-Y dalam aspek Selama Berwisata ada 3 hal yaitu : (1). Pilihan utama akomodasi selama berwisata, mayoritas Gen-X lebih menyukai Hotel Berbintang, lalu Homestay/Pondok Wisata, Penginapan Non Bintang, dan di Rumah keluarga/teman. Sedangkan mayoritas Gen-Y lebih menyukai Pondok Wisata/Home Stay, kemudian Hotel Berbintang, Rumah keluarga/ teman dan Hotel Non-Bintang. Hal tersebut karena anggaran berwisata Millenial lebih terbatas dibanding Gen-X. Sedangkan bagi Gen-X, rumah saudara atau teman merupakan pilihan akomodasi terakhir, karena bagi mereka yang mayoritas sudah berkeluarga meyakini hal tersebut akan merepotkan pemilik rumah. (2) Faktor yang paling menentukan dalam memilih tempat makan selama berwisata, mayoritas Gen-X lebih mementingkan Tampilan \& kebersihan, lalu faktor Lokasinya kemudian Harga. Sedangkan mayoritas Gen-Y lebih cenderung memilih Harga serta Tampilan dan Kebersihan lalu Lokasi tempat makan tersebut. (3) Jenis tempat makan yang disukai selama berwisata oleh Gen-X adalah Tempat makan khas daerah, lalu Tempat makan yang murah, diikuti restoran cepat saji dan Cafe/Restoran besar. Untuk Millenial, mayoritas mereka lebih menyukai Tempat makan yang murah, lalu tempat makanan khas daerah, kemudian restoran cepat saji dan Cafe/Restoran besar. Bagi Generasi Millenial, mereka lebih menyukai Tempat makan yang murah karena anggaran berwisatanya lebih terbatas dibanding Gen-X.

\section{Paska Berwisata}

Dalam aspek Paska Berwisata, Gen-X dan Gen-Y memiliki 2 hal perbedaan prilaku yaitu (1) Aktivitas yang paling sering dilakukan setelah menikmati produk atau jasa wisata, dimana mayoritas Gen-X lebih menyukai Upload photo di media sosial, lalu tulis komentar di media sosial, kemudian memberi tip dan tulis komentar di website resmi. Namun mayoritas Gen-Y lebih menyukai upload photo di media sosial, lalu memberi tip, dan terakhir tulis komentar di media sosial dan website resmi. (2). Media yang digunakan untuk berbagi pengalaman berwisata bagi mayoritas Gen-X adalah lebih menyukai Upload photo, dan menulis di media sosial Instagram, Face Book, Trip Advisor, lalu Twitter dan Line. Sedangkan mayoritas Gen-Y lebih menyenangi Upload photo dan berbagi pengalaman berwisata di Instagram, kemudian Face Book, Twitter, Line, lalu terakhir Trip Advisor. Disamping Upload photo, generasi Millenial lebih menyukai menulis komentar di semua jejaring sosial yang sifatnya lebih personal yaitu Instagram, Facebook, Twitter dan Line, baru terakhir menulis di Trip Advisor.

\section{SIMPULAN}

Kajian tentang studi komparasi dua generasi yaitu Gen-X dan Gen-Y (Millenial) pada kasus wisatawan nusantara yang berkunjung ke Kota Bogor, dapat disimpulkan bahwa kedua generasi tersebut memiliki lebih banyak persamaan dalam hal perilaku berwisata dibandingkan dengan perbedaannya. Persamaan tersebut adalah pada variabel Selama Berwisata dan variabel Proses Pengambilan Keputusan Berwisata aspek Motivasi, Mencari Informasi, dan Penilaian. Perbedaan yang cukup signifikan antara Gen-X dan Gen-Y yaitu pada variabel Paska 
Berwisata, dan Variabel Proses Pengambilan Keputusan Berwisata aspek Inisiasi dan Pengambilan Keputusan.

\section{DAFTAR PUSTAKA}

Adi, P.R.P., \& Indrawati, K.A., (2019). Perbedaan Keterikatan Kerja $\quad$ berdasarkan Generasi Kerja Karyawan pada Perusahaan Berkonsep THK ditinjau dari Etos Kerja. Jurnal Psikologi Udayana,Edisi Khusus Kesehatan Mental, hal. 46-57.

APJII. Survey Asoisasi Pengguna Jasa Internet Indonesia. Diakses tanggal 20 Februari 2020. https://apjii.or.id/survei2018/.

APJII. Survey Asosiasi Pengguna Jasa Internet Indonesia. Diakses tanggal 20 Februari 2020. https://apjii.or.id/survei2019/ .

Bhaskara, G.I. (2017). Media Sosial dan Industri Pariwisata di Bali . Universitas Udayana. simdos.unud.ac.id

Benckendorff, P., Moscardo, G., \& Pendergast, D. (2010). Tourism and generation Y. Wallingford, CT: CABI Publishing.

Binus. (2019). Mengenal lebih jauh Revolusi Industri 4.0. Binus University Knowledge Management \& Innovation. (https://binus.ac.id/knowledge/2019/05/mengenal-lebihjauh-revolusi-industri-4-0/). Diakses tanggal 21 Februari 2020.

Campo, R., Haggerty, L., Haney, M. \& Knippel. (2011). Managing the multi-generational workforce: from the gi generation to the millennials. Burlington: Gower Publishing.

Cavagnaro, E., Staffieri S., \& Postma A. (2018). Understanding millennials' tourism experience: values and meaning to travel as a key for identifying target clusters for youth (sustainable) tourism. Journal of Tourism Futures, Vol. 4 (1). pp. 31-42, Emerald Publishing Limited, DOI 10.1108/JTF-12-2017-005.

Cohen, S.A., Prayag, G. \& Moital, M. (2014). Consumer Behaviour in Tourism: Concepts, influences and opportunities, Current Issues in Tourism, DOI: $10.100 / 13683500.2013 .850064$

Gardiner, S., Grace D., King, C. (2014). The generation effect: The future of domestic tourism in Australia. Journal of travel research, Vol. 53 (6), pp 705-720.

Gursoy, D., Maier, T.A., Chi, C.G. (2008). Generational differences: An examination of work values and generational gaps in the hospitality workforce. International Journal of Hospitality Management, Vol. 27(3), pp 448-458.

Hasanuddin Ali, Purwandi, L., Nugroho, H., Anastasia, W., Ekoputri, \& Halim, T. ( 2016). Indonesia 2020: The Urban Middle Class Millenials. Alvara Research Center. (https://www.researchgate.net/publication/314448735). Diakses 11 Februari 2020.

Kotler, Bowen, Makens. (2013). Marketing for Hospitality and Tourism. $6^{\text {th }}$ Edition. Pearson Prentice Hall. United States of America. 
Miles, M.B., Huberman, A.M., \& Saldana, J. (2014). Qualitative Data Analysis: A Methods Sourcebook. Third Edition. SAGE Publications Ltd (CA).

Rita,P., Brochado, A., \& Dimova, L. (2018). Millennials' travel motivations and desired activities within destinations: A comparative study of the US and the UK, Current Issues in Tourism, DOI: 10.1080/13683500.2018.1439902.

Ristekdikti. (2018). Era-revolusi industri 4-0 saatnya generasi millennial menjadi dosen masa- depan (http://sumberdaya.ristekdikti.go.id/index.php/2018/01/30/era-revolusiindustri-4-0-saatnya-generasi-millennial-menjadi-dosen-masa-depan/).Diakses tanggal 14 Februari 2020.

Sladana Starĉević, Snezana Konjikušić. (2018). Why Millenials as Digital Traveller Transfromed Marketing Startegy in Tourism Industry. Researchgate (https://www.researchgate.net/publication/328791775). Diakses 3 Februari 2020.

Soeswoyo,D.M., Dewi, L., \& Asparani. (2018). Promosi Melalui Media Sosial Berbasis Partisipasi Masyarakat dan Peranannya dalam Pariwisata Kota. Jurnal Pariwisata, Vol 5(2), Hal. 156-164.

Soeswoyo, D.M. \& Nurmawanti, D. (2016). Marketing Stimuli yang Berpengaruh Terhadap Keputusan Pembelian Paket Wisata Domestik Grup. Jurnal Pariwisata, Vol 3(2) , Hal. 83-94.

Teknoia. Diakses tanggal 4 Februari 2020. https://teknoia.com/data-internet-diindonesiadanperilakunya880c7bc7cd19.

UNWTO Report \& WYSE Travel Confederation Report. Diakses 18 Februari 2020. https://www.eunwto.org/doi/book/10.18111/9789284417162

Veiga, C. et al. (2017). Are Millennials Transforming Global Tourism? Challenges for destinations and companies, Worldwide Hospitality and Tourism Themes, Vol. 9(6), pp 603-616.

Wiweka, K., Wachyuni, S.S., Rini, N.A., Adnyana, I.N., Adnyana, P.P. (2019). Perilaku Berwisata Wisatawan Generasi Millenial di Jakarta pada Era Revolusi Industti 4.0. Jurnal Sains Terapan Pariwisata. Vol. 4 (3). 